\title{
Analysis of Watersheds in Gandaki Province, Nepal Using QGIS
}

\author{
Keshav Basnet*, Er. Ram Chandra Paudel and Bikash Sherchan \\ Infrastructure Engineering and Management Program \\ Department of Civil and Geomatics Engineering \\ Pashchimanchal Campus, Institute of Engineering \\ Tribhuvan University, Nepal \\ *Email: basnet.keshav@gmail.com
}

\begin{abstract}
Gandaki province has the good potentiality of hydro-electricity generation with existing twentynine hydro-electricity projects. Since the Province is rich in water resources, analysis of watersheds needs to be done for management, planning and identification of water as well as natural resources. GIS offers integration of spatial and no spatial data to understand and analyze the watershed processes and helps in drawing a plan for integrated watershed development and management. The Digital Elevation Model (DEM) available on the NASA-Earth data has been taken as a primary data for morphometric analysis of watershed in Gandaki Province using QGIS. Delineation of watershed was conducted from a DEM by computing the flow direction and using it in the Watershed tool. Necessary fill sink correction was made before proceeding to delineation. A raster representing the direction of flow was created using Flow Direction tool to determine contributing area. Flow accumulation raster was created from flow direction raster using Flow Accumulation Tool. A pointbased method has been used to delineate watershed for each selected point. The selected point may be an outlet, a gauge station or a dam. The annual rainfall data from ground meteorological stations has been used in QGIS to generate rainfall map for the study of rainfall pattern in the province and watersheds using IDW Interpolation method. The present research work provides some major morphometric watershed parameters like drainage area, flow length, slope, drainage density and rainfall patterns for watersheds in Gandaki Province. Furthermore, the parameters were compared among the watersheds in Kaski. The results of this study can be used as a reference for proposing infrastructures in those watersheds and it can also be used for making policy by local government authorities related to Energy, Water Resources, Irrigation, and Infrastructures.
\end{abstract}

Keywords: Hydrologic analysis; Hydrologic modeling; Watershed parameters; Morphometric parameters; Phewa watershed. 


\section{Introduction}

Gandaki province has the good potentiality of hydro-electricity generation with existing 29 hydro-electricity projects (Sahayogee, n.d.). Number of lakes and perennial rivers can be attributed to the richness in water resources in this province. The province is drained by the tributaries of the river Gandaki (Kali Gandaki, Budhi Gandaki, Seti Gandaki, Marshyangdi, Madi, Daraundi, and Seti). This province is rich in lakes as well with Phewa, Rupa, Begnas, Khaste, Dipang, and Tilicho lakes to name a few. According to the Statistic Office Kaski, Central Bureau Statistics, the Gandaki Province covers an area of $21,773 \mathrm{~km}^{2}$ which is about $14.66 \%$ of the total area of Nepal. The Province is extending between $27^{\circ}-20^{\prime} \mathrm{N}$ to $29^{\circ}-20^{\prime} \mathrm{N}$ latitude and $82^{\circ}-52^{\prime} \mathrm{E}$ to $85^{\circ}-12^{\prime} \mathrm{E}$ longitude. In terms of terrain, the province is spread over the Himalayan, Hilly and Terai regions of Nepal; $5,919 \mathrm{~km}^{2}(26.8 \%)$ of the area falls under the Himalayan region, $14,604 \mathrm{~km}^{2}(67.2 \%)$ of the area falls under the Hilly region, and $1,310 \mathrm{~km}^{2}(6 \%)$ of the area falls under the Terai region (Province Profile, Province No. 4). Hydrological studies are important and necessary for water and environmental resources management. Demands from society on the predictive capabilities of such study and analysis of hydrological parameters are becoming higher and higher, leading to the need of enhancing existing research theories and even on developing new theories. For example, hydrological analysis is critical to design road side drains for better management of storm water in major cities of Nepal. Basnet and Neupane
(2018) performed hydrologic analysis for the purpose of designing storm water drainage in the area of Lamachaur, Pokhara, Nepal. They found the existing drainage system of Lamachaur area is inadequate to safely discharge the surface water based on hydrologic analysis. Since the Gandaki Province is rich in water resources, the comprehensive hydrological study of watersheds yet to be done by local government and authorities related to water resource for management, planning and identification of water as well as natural resources. Basnet et al. (2018) conducted comparative hydrological study of common approaches used for calculation of design discharge. They concluded that the Catchment Area Ratio method found to be suitable one for estimating the design discharge of Padhu Khola, Kaski, Nepal. The present research performed hydrologic modeling to study watersheds within Gandaki Province. The major focus was given to Kaski District and Phewa Watershed (see Figure 1 and Figure $2)$. The Phewa Lake Watershed (28 $11^{\prime} 39^{\prime \prime}$ to $28^{\circ} 17^{\prime} 25^{\prime \prime} \mathrm{N}$ and $83^{\circ} 47^{\prime} 51^{\prime \prime}$ to $83^{\circ} 59^{\prime} 17^{\prime \prime} \mathrm{E}$ ) is a micro region of the hill of Nepal. It lies in the west of Pokhara Metropolitan City (Former Pokhara Sub-metropolitan City) covering about $122.53 \mathrm{~km}^{2}$ area with the elevation from the sea level between $793 \mathrm{~m}$ and $2508.81 \mathrm{~m}$. Some 5.75 $\mathrm{km}^{2}$ area of Phewa Lake watershed realm lies in Pokhara City and occupies 38\% population of the city (Aryal, 2007). 


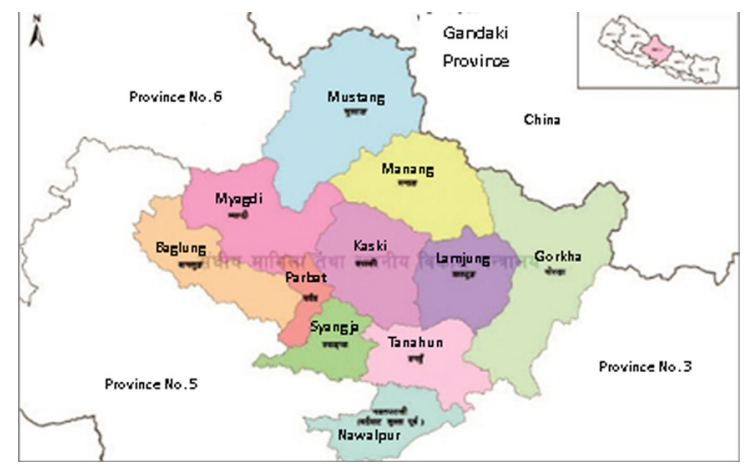

Figure 1: Map of Gandaki Province

(Source: Provincial Government, Gandaki Province)

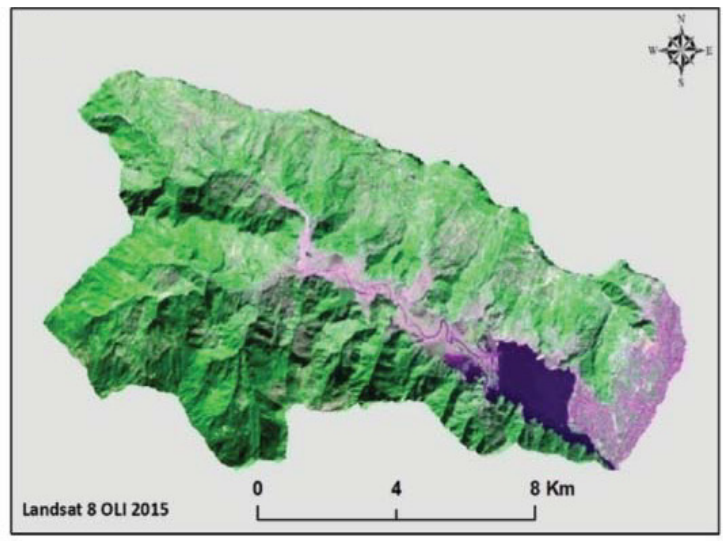

Figure 2: Landsat (MSS, OLI and TM) image of Phewa watershed (Source: United States Geological Survey web portal: http:// earthexplorer.usgs.gov)

The main goal of the present research work is to determine morphometric parameters of the watersheds in Gandaki Province of Nepal using QGIS. Specifically, the research work intends to achieve the following objectives:

a) To acquire and generate GIS data layers for study area. These layers include Digital Elevation Models (DEMs), digital raster graphic maps (DRGs), National, Provincial and District boundaries.

b) To use DEM to delineate the watersheds and sub-basins and determine morphometric parameters: (a) Drainage Area, (b) Watershed Length, (c) Watershed Slope, (d) Flow Length, (e) Drainage Density, and (f) Watershed Shape Factors using QGIS.

c) To use rainfall data from TRMM and ground meteorological stations to generate rainfall map of sub-basins.

Recently, Nepal has gone into federal system and there are challenges for every province to manage administrative system first, secondly the management of water resource in order to prioritize the major concern. In Gandaki Province where there are numbers of lakes and water basins exist, it is very important to manage these water resources and watersheds for proper development of the province and for predicting and managing future water demand. One of the major tasks for this would be analysis of watersheds in Gandaki Province. Watershed analysis provides not only their boundaries but also hydrological parameters useful for management programs like decision making. It helps in flood prediction modeling and snow melt runoff models and provides necessary inputs for hydrological modeling. Being concentrated on the analysis of watersheds in Gandaki Province, especially near Kaski area, this research work has various significances (e.g., water management programs, water resource identification and management, and flood prediction and control).

As the purpose of this study was to generate watershed parameters/characteristics for control point in Gandaki Province in basic level, 
morphometric characteristics of watersheds are only the output of this study in general. Detail study needs advanced level analysis considering discharge, interbrain flow, etc. This study uses $30 \mathrm{~m}$ DEM for analysis of sub-basins in the Gandaki Province, the DEM also have $\mathrm{Z}$ accuracies generally between $10 \mathrm{~m}$ and $25 \mathrm{~m}$ root mean square error (RMSE).

\section{Material and Methods}

\subsection{Data Acquisitions and Program Setup}

Achieving objectives required research into what data sets are available and which ones best suit the needs of the research (Mason \& Maidment, 2000). The main sources of data acquisition were the Nepal Government Geo Portal, ICIMOD, USGS, NASA-Earth data, TRMM, Alaska Satellite Facility, and The Humanitarian Data Exchange (HDX), all of which provide GIS data layers that are essential for this study. Most of the data layers were obtained by downloading them from the official websites of the above-mentioned agencies, and local resources where open source spatial data of Remote Sensing and GIS are available.

Once all the necessary spatial datasets for the Gandaki Province were collected, the next step was to process and analyze the spatial data using 'QGIS Desktop 2.18' computer program. It is very critical to assign and use consistent coordinate system for all datasets used in delineating watershed by so all the spatial datasets were assigned a researched coordinate system of WGS 1984 UTM Zone 44N.

\subsection{Watershed Delineation Steps}

Authors proceed through a series of steps as shown in Figure 3 while delineating watersheds or defining stream networks.

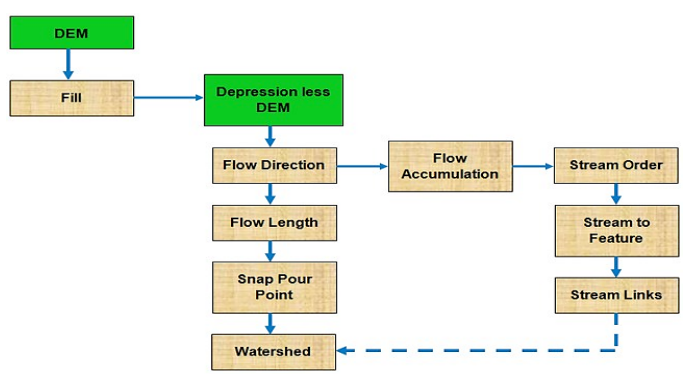

Figure 3: Steps involved in delineation of watershed (Source: GIS Resources: A Knowledge Archive) DEM (Digital Elevation Model) is the principal input required for watershed analysis. Value in each cell corresponds to its elevation (z- values are regularly spaced intervals) representing the terrain over the "Bare Earth". A depression in a DEM is unavoidable, which in fact is a cell that is surrounded by higher elevation cells. Although some depressions are real, such as quarries or glaciated potholes, are considered imperfections in the DEM for the subsequent steps in the watershed analysis. Therefore, depressions must be removed. A common method to remove depression is to increase its cell value to the lowest overflow point out of the sink resulting in a flat surface. With the filled DEM, flow direction raster is generated which represents the direction of flow of water out of each cell. A widely used method is the D8 method which assigns a cell's flow direction to the one of its eight immediate surrounding cells that has the steepest distance-weighted gradient. In the next step, flow accumulation tool tabulates for each cell, the number of cells 
that will flow to it. The tabulation is based on the flow direction raster. A flow accumulation raster can be interpreted in the following two ways.
a) Cells having accumulation values generally correspond to stream channels, whereas cells having an accumulation value of zero generally correspond to ridgelines.
b) If multiplied by cell size, the accumulation value equals to drainage area.

Flow accumulation raster already represent stream network with the accumulation surface in the background. However, actual stream network can be derived from a flow accumulation raster. The derivation is based on a threshold accumulation value. A threshold value of 500, for example, means that each cell of the drainage network has a maximum of 500 contributing cells. A higher threshold value will result in a less dense stream network and fewer internal watersheds than lower threshold value. Threshold values between 100 to 500 cells seem to best capture the stream network in the area.

Assigning a unique value and associating with flow direction to each section of stream network is a step or procedure to derive stream links. A stream link raster therefore resembles a topology-based stream layer: the intersections or junctions are like arcs or reaches.

Finally, watershed is delineated and there are two different methods namely area-wide watershed and point-based watersheds. Inputs required for area-wide watershed delineation are flow direction raster and stream link raster. A denser stream network will have more but smaller watersheds. Point based watersheds delineation is based on the point of interest. This point of interest may be stream gauge stations or dams. They may also correspond to surface drinking water system intake points of interest are called pour point or outlets. If pour point is not located directly over a stream link, it will result in a small, incomplete watershed for the outlet.

Watershed boundaries, stream network, waterways, drain direction, etc., were analyzed using raster file and converted to vector using raster to vector conversion tool for every point, lines and polygons and calculation of those parameter were done using different functions like area, length, slope calculator provided by 'QGIS Desktop 2.18'.

\subsection{IDW Interpolation Method}

Inverse distance weighted (IDW) interpolation explicitly makes the assumption that things, which are close to one another, are more alike than those that are farther apart (Figure 4 and Figure 5). To predict a value for any unmeasured location, IDW uses the measured values surrounding the prediction location. The measured values closest to the prediction location have more influence on the predicted value than those farther away. IDW assumes that each measured point has a local influence that diminishes with distance. It gives greater weights to points closest to the prediction location, and the weights diminish as a function of distance as it named inverse distance weighted. 


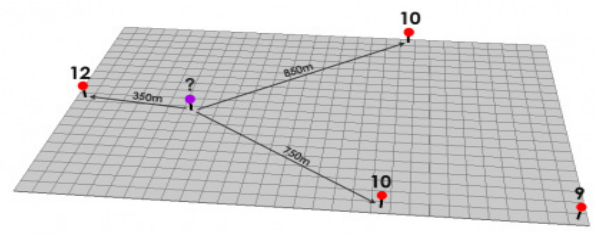

Figure 4: Unknown z value

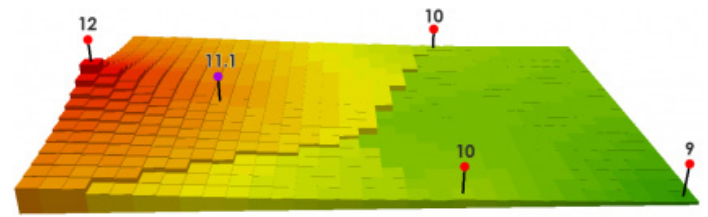

Figure 5: Determination of value of $\mathrm{z}$ using IDW

Interpolated points are estimated based on their distance from known cell values. Points that are closer to known values will be more influenced than points that are farther away. The formula is given below where the sigma notation simply means that adding whatever number of points that will be interpolated. Here the authors simply summing the elevation values at each point with respect to distance.

$$
Z_{p}=\frac{\sum_{i=1}^{n}\left(\frac{z_{i}}{d_{i}^{p}}\right)}{\sum_{i=1}^{n}\left(\frac{1}{d_{i}^{p}}\right)}
$$

\section{Results and Discussion}

\subsection{A Comparison with Previous Studies}

Lake Watershed has been a focus point for research around the globe. It is found that several previous studies have been already conducted on Phewa Lake Watershed. Here is a comparison between this and previous studies. The polygon of Phewa Lake Watershed obtained from the analysis was compared with the Satellite image used by (Subedi, 2013) in
Figure 6. Booth seems quite similar in shape, size, and orientations that validate the method of analysis. Therefore, this method can be used in other watersheds too. Figure 7 shows the stream networks of Kaski district obtained from the analysis and the stream networks from Subedi (2013), where both seems quite similar in shape, size and orientations, which validates the method of analysis. Table 1 illustrates the comparison of facts for Phewa Lake Watershed form present study with previous studies. The results of present research found comparable with the results of previous studies which validates the data, program and the method used in analysis of this study. Hence this method can be used in other regions too.

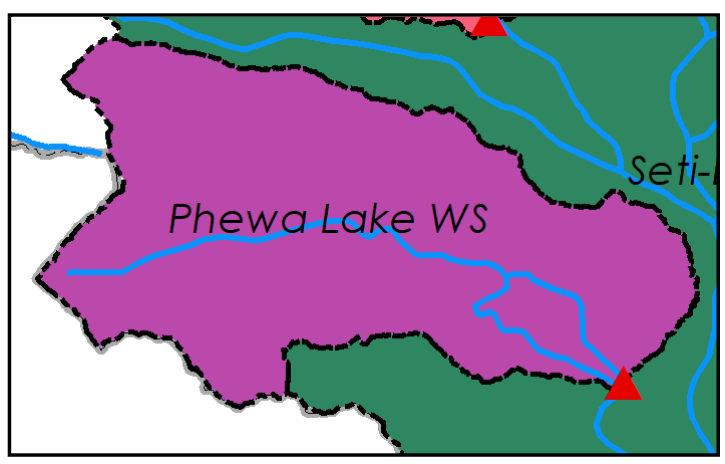

(a) Result from this study

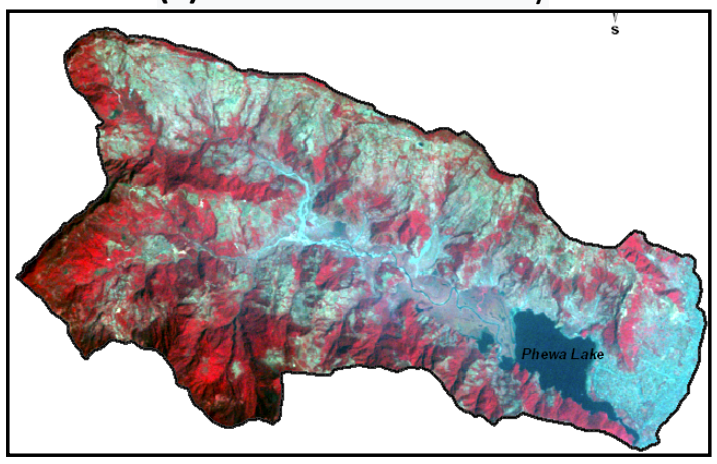

(b) From Subedi (2013)

Figure 6: Comparison of Phewa Lake Watershed with previous study 


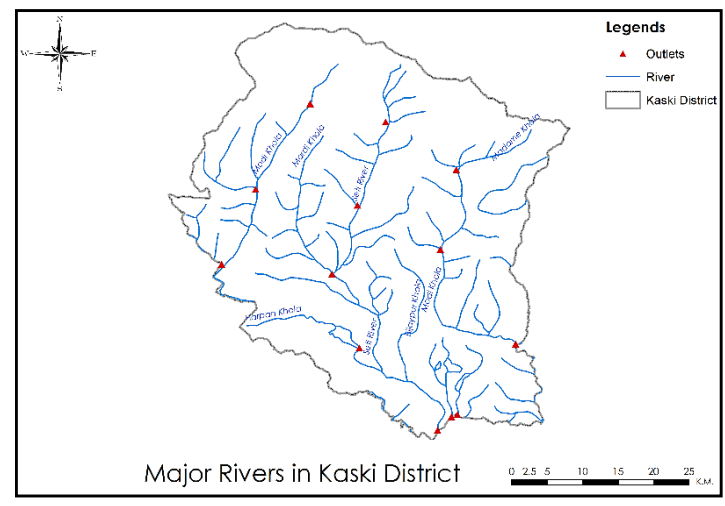

(a) Result from this study

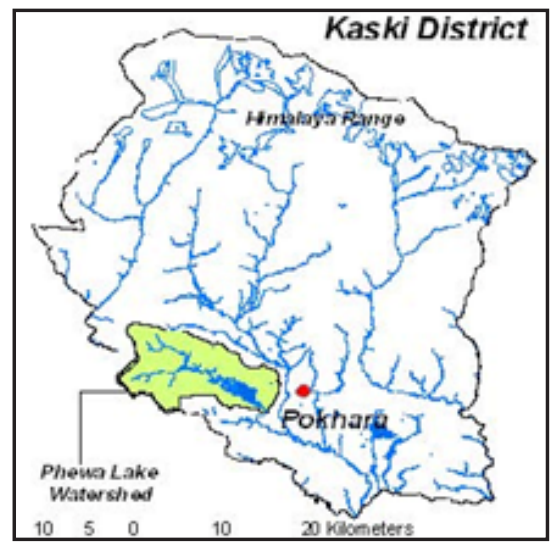

(b) from Subedi (2013)

Figure 7: Comparison of Kaski District

Streams with previous study

Table 1: Comparison of major parameters for present research and previous studies

\begin{tabular}{|l|l|l|l|l|l|}
\hline $\begin{array}{l}\text { S. } \\
\text { N. }\end{array}$ & Parameters & This Study & $\begin{array}{l}\text { Subedi } \\
\mathbf{( 2 0 1 3 )}\end{array}$ & $\begin{array}{l}\text { Aryal } \\
\mathbf{( 2 0 0 7 )}\end{array}$ & Remarks \\
\hline 1. & $\begin{array}{l}\text { Area } \\
\text { derived }\end{array}$ & $121.61 \mathrm{~km}^{2}$ & $119.89 \mathrm{~km}^{2}$ & $122.53 \mathrm{~km}^{2}$ & Comparable \\
\hline 2. & Shape & As shown & As shown & - & Comparable \\
\hline 3. & $\begin{array}{l}\text { Stream } \\
\text { Network }\end{array}$ & As shown & As shown & - & Comparable \\
\hline 4. & DEM (m.) & $\begin{array}{l}12.5 \mathrm{~m} \mathrm{x} \\
12.5 \mathrm{~m}\end{array}$ & $\begin{array}{l}30.0 \mathrm{~m} \mathrm{x} \\
30.0 \mathrm{~m}\end{array}$ & - & $\begin{array}{l}\text { Used fine DEM } \\
\text { in this study }\end{array}$ \\
\hline 5. & Outlet & $\begin{array}{l}\text { Phewa } \\
\text { Dam }\end{array}$ & - & - & Same \\
\hline 6. & Software & QGIS & Arc GIS & - & - \\
\hline
\end{tabular}

\subsection{Watershed Analysis of Gandaki Province}

Being rich in water resources, water management and planning should be the top concern of the Gandaki Province Government (Officially, Government of Gandaki Pradesh). Watershed analysis can be one of the key ideas for the management and planning of water and natural resources. Watersheds parameters can be used as a reference for proposing infrastructures in those watersheds and it can also be used for making policy by local government authorities related to Energy, Water Resources, Irrigation, and Infrastructures.

Provincial boundary of Nepal, officially the Federal Democratic Republic of Nepal, can be seen in Figure 8. Gandaki Province is one of the seven provinces of Nepal. This layer was acquired from Geo Portal Nepal official website and necessary processing was done by using QGIS Desktop 2.18 program for the presentation. Figure 9 shows the major rivers of Nepal and Hydrological Stations; the rivers were delineated from ASTER Global DEM available freely upon request on NASA-Earth data with spatial resolution of $30 \mathrm{~m} \times 30 \mathrm{~m}$. The location of hydrological Station was taken from Department of Hydrology and Meteorology (DHM) official website. These station locations were taken as a reference to choose outlets of sub-basins. Sub-basins in Gandaki Province that are delineated using ASTER Global DEM are presented in Figure 10. From the analysis it was found that there are nine numbers of sub-basins in Gandaki Province, where only two of them completely lie within the province boundary and they are East Seti Sub-Basin and Marshyangdi Sub-Basin. The rest seven sub-basins are partially lying in the Gandaki Province. The 
majority of area is occupied by Kali Gandaki Sub-Basin with $11839.8 \mathrm{~km}^{2}$ drainage area and minimum area is occupied by East Seti SubBasin with $2959.02 \mathrm{~km}^{2}$ drainage area. East Seti Sub-Basin has higher slope of 0.0307 and Tinahu Sub-Basin has lesser slope of 0.0076. Average annual rainfall distribution of Nepal and the average annual rainfall distribution of sub-basins are shown in Figure 11 and Figure 12 respectively. The rainfall map has been prepared from open source HDX data (1980-2000) by using Inverse Distance Weighted (IDW) Interpolation method. The rainfall map form TRMM (Tropical Rainfall Measuring Mission), a joint space mission between NASA and the Japan Aerospace Exploration Agency designed to monitor and study tropical rainfall, has also been taken as a reference. From the analysis it was found that the maximum average annual Rainfall had been occur in Kali Gandaki SubBasin and minimum average annual rainfall had been occur within West Rapti Sub-Basin.

Morphometric parameters of sub-basins from the analysis are presented in tabulated form in Table 2. The sub-basin parameters were calculated by using geometrical and statistical tool in QGIS. The highlighted sub-basins are completely or majority of area lies within the boundary of Gandaki Province. The purpose of this study was to generate watershed parameters/ characteristics for control point in Gandaki Province in basic level. Considering Interbasin flow, discharge data from hydrological stations may lead to advance level of study in the province. Recent rainfall data from meteorological stations can be incorporated to prepare rainfall map which helps to study current trends of rainfall in the province.

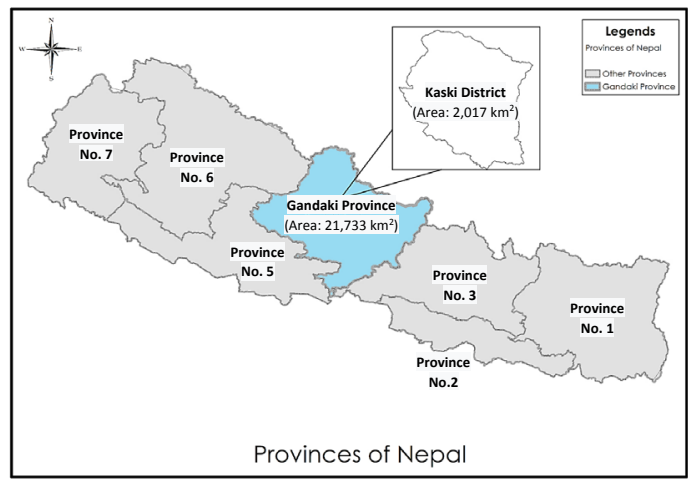

Figure 8: Provincial boundaries of Nepal

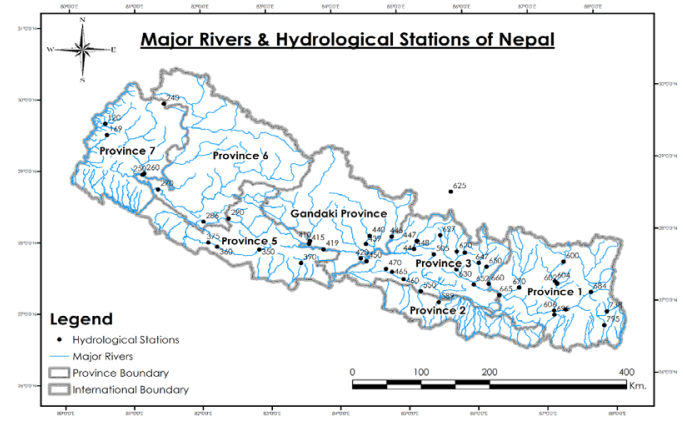

Figure 9: Major Rivers and Hydrological

\section{Stations of Nepal}

Table 2: Morphometric parameters of sub-basins

\begin{tabular}{|c|c|c|c|c|c|c|c|}
\hline S. N. & Sub Basins & Major River & $\begin{array}{c}\text { Drainage } \\
\text { Area } \\
\text { (Sq.Km.) }\end{array}$ & \begin{tabular}{|c|} 
Perimeter \\
$(\mathrm{Km})$.
\end{tabular} & $\begin{array}{c}\text { WS } \\
\text { Length } \\
(\mathrm{Km} .)\end{array}$ & $\begin{array}{c}\text { Flow } \\
\text { Length } \\
(\mathrm{Km} .)\end{array}$ & $\begin{array}{c}\text { Drainage } \\
\text { Density }\end{array}$ \\
\hline 1 & $\begin{array}{l}\text { Kali Gandaki } \\
\text { Sub-Basin }\end{array}$ & $\begin{array}{l}\text { Kali Gandaki } \\
\text { River }\end{array}$ & i 11839.800 & 861.125 & 393.344 & 786.189 & 0.066 \\
\hline 2 & $\begin{array}{l}\text { Marshyangdi } \\
\text { Sub-Basin }\end{array}$ & $\begin{array}{l}\text { Marshyangdi } \\
\text { River }\end{array}$ & 4798.660 & 443.600 & 166.781 & 233.913 & 0.049 \\
\hline 3 & $\begin{array}{l}\text { East Seti Sub- } \\
\text { Basin }\end{array}$ & Seti River & 2954.020 & 330.327 & 143.712 & 223.468 & 0.076 \\
\hline 4 & $\begin{array}{l}\text { Thuli Bheri Sub- } \\
\text { Basin }\end{array}$ & Bheri River & 13678.800 & 879.132 & 330.224 & 956.026 & 0.070 \\
\hline 5 & $\begin{array}{l}\text { East Rapti Sub- } \\
\text { Basin }\end{array}$ & Rapti River & 4707.600 & 503.917 & 222.460 & 379.310 & 0.081 \\
\hline 6 & $\begin{array}{l}\text { West Rapti Sub- } \\
\text { Basin }\end{array}$ & Rapti River & 6282.070 & 642.272 & 305.152 & 561.978 & 0.089 \\
\hline 7 & $\begin{array}{l}\text { Tinahu Sub- } \\
\text { Basin }\end{array}$ & Tinahu River & 4569.490 & 447.986 & 91.437 & 426.445 & 0.093 \\
\hline 8 & $\begin{array}{l}\text { Budhi Gandaki } \\
\text { Sub-Basin }\end{array}$ & $\begin{array}{l}\text { Budhi Gandaki } \\
\text { River }\end{array}$ & 3621.240 & 415.984 & 127.446 & 274.761 & 0.076 \\
\hline 9 & $\begin{array}{l}\text { Trishuli Sub- } \\
\text { Basin }\end{array}$ & Trishuli River & 4117.620 & 534.624 & 219.274 & 417.673 & 0.101 \\
\hline
\end{tabular}




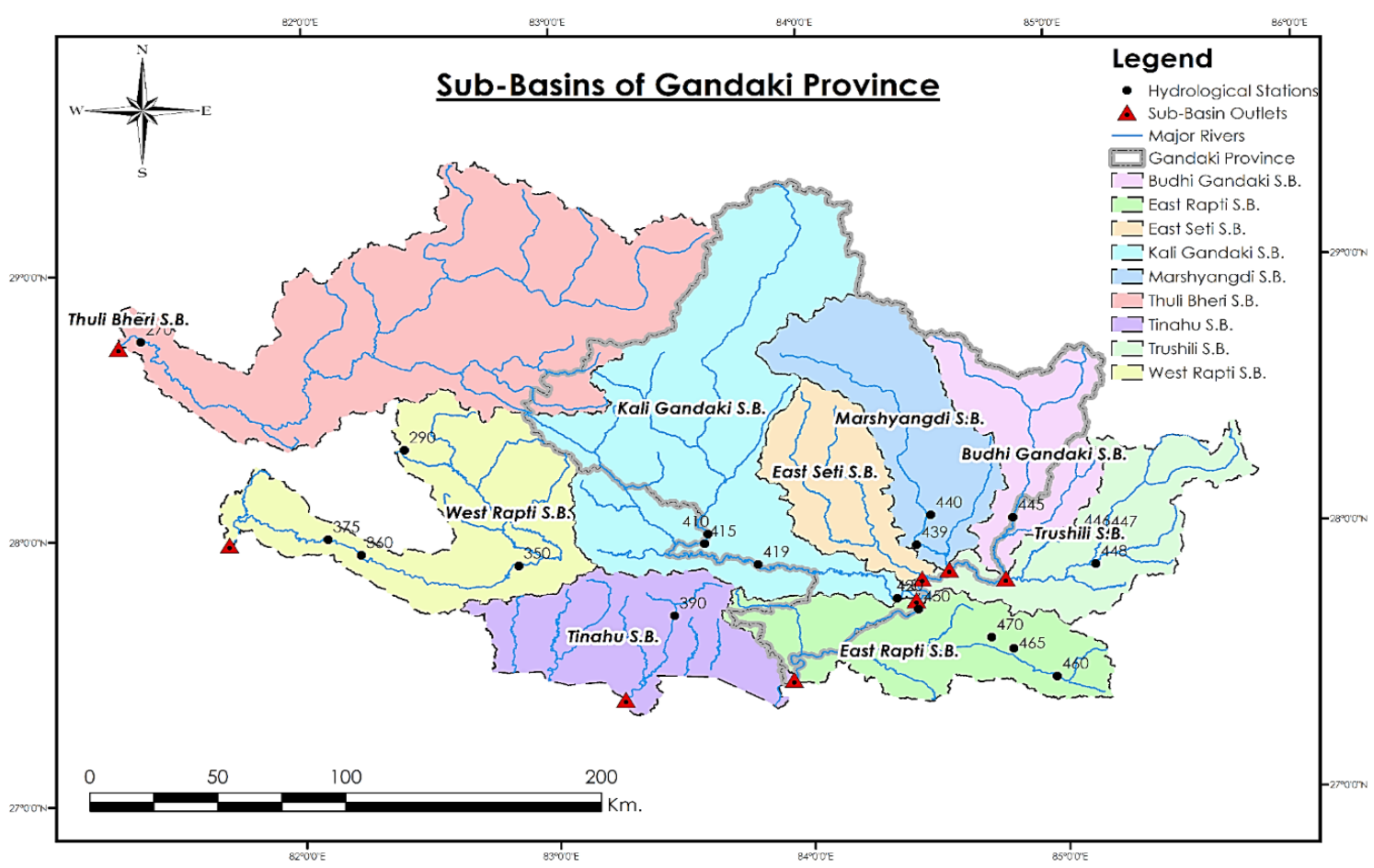

Figure 10: Sub-basins of Gandaki Province

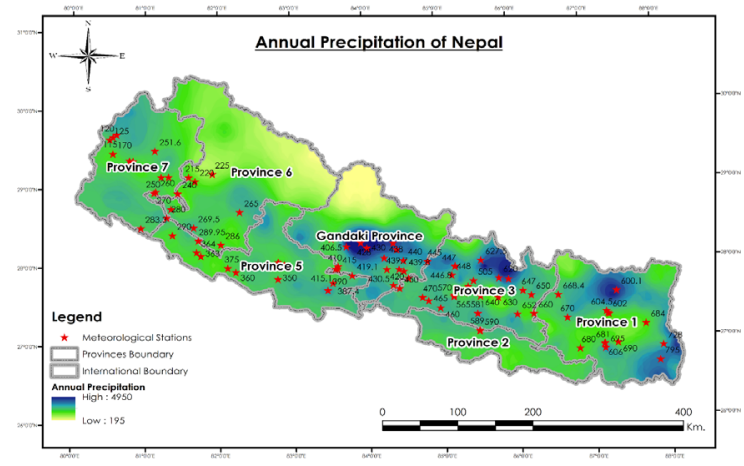

Figure 11: Annual Precipitation of Nepal
Table 2 contd.: Morphometric parameters of sub-basins

\begin{tabular}{|c|c|c|c|c|c|c|c|c|}
\hline \multirow[b]{2}{*}{ S. N } & \multirow[b]{2}{*}{ Sub Basins } & \multicolumn{2}{|c|}{ Elevation } & \multirow{2}{*}{ 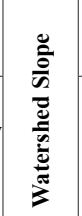 } & \multicolumn{2}{|c|}{$\begin{array}{l}\text { WS Shape } \\
\text { Factor }\end{array}$} & \multicolumn{2}{|c|}{$\begin{array}{c}\text { Annual } \\
\text { Precipitation }\end{array}$} \\
\hline & & $\begin{array}{l}\text { High } \\
(\mathrm{m} .)\end{array}$ & $\begin{array}{l}\text { Low } \\
(\mathbf{m} .)\end{array}$ & & 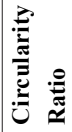 & 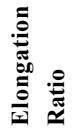 & 离 & 离离 \\
\hline 1 & $\begin{array}{l}\text { Kali Gandaki } \\
\text { Sub-Basin }\end{array}$ & 5020 & 180 & 0.0123 & 2.232 & 0.312 & 4990 & 195 \\
\hline 2 & $\begin{array}{l}\text { Marshyangdi } \\
\text { Sub-Basin }\end{array}$ & 4333 & 261 & 0.0244 & 1.806 & 0.469 & 3550 & 330 \\
\hline 3 & $\begin{array}{l}\text { East Seti Sub- } \\
\text { Basin }\end{array}$ & 4631 & 219 & 0.0307 & 1.714 & 0.427 & 4950 & 1450 \\
\hline 4 & $\begin{array}{l}\text { Thuli Bheri Sub- } \\
\text { Basin }\end{array}$ & 5368 & 226 & 0.0156 & 2.120 & 0.400 & 2750 & 340 \\
\hline 5 & $\begin{array}{l}\text { East Rapti Sub- } \\
\text { Basin }\end{array}$ & 2068 & 124 & 0.0087 & 2.072 & 0.348 & 2810 & 1935 \\
\hline 6 & $\begin{array}{l}\text { West Rapti Sub- } \\
\text { Basin }\end{array}$ & 2492 & 125 & 0.0078 & 2.286 & 0.293 & 2700 & 1335 \\
\hline 7 & $\begin{array}{l}\text { Tinahu Sub- } \\
\text { Basin }\end{array}$ & 781 & 82 & 0.0076 & 1.870 & 0.834 & 2585 & 1705 \\
\hline 8 & $\begin{array}{l}\text { Budhi Gandaki } \\
\text { Sub-Basin }\end{array}$ & 5560 & 326 & 0.0411 & 1.950 & 0.533 & 3175 & 950 \\
\hline 9 & $\begin{array}{l}\text { Trishuli Sub- } \\
\text { Basin }\end{array}$ & 5350 & 180 & 0.0236 & 2.350 & 0.330 & 3175 & 995 \\
\hline
\end{tabular}




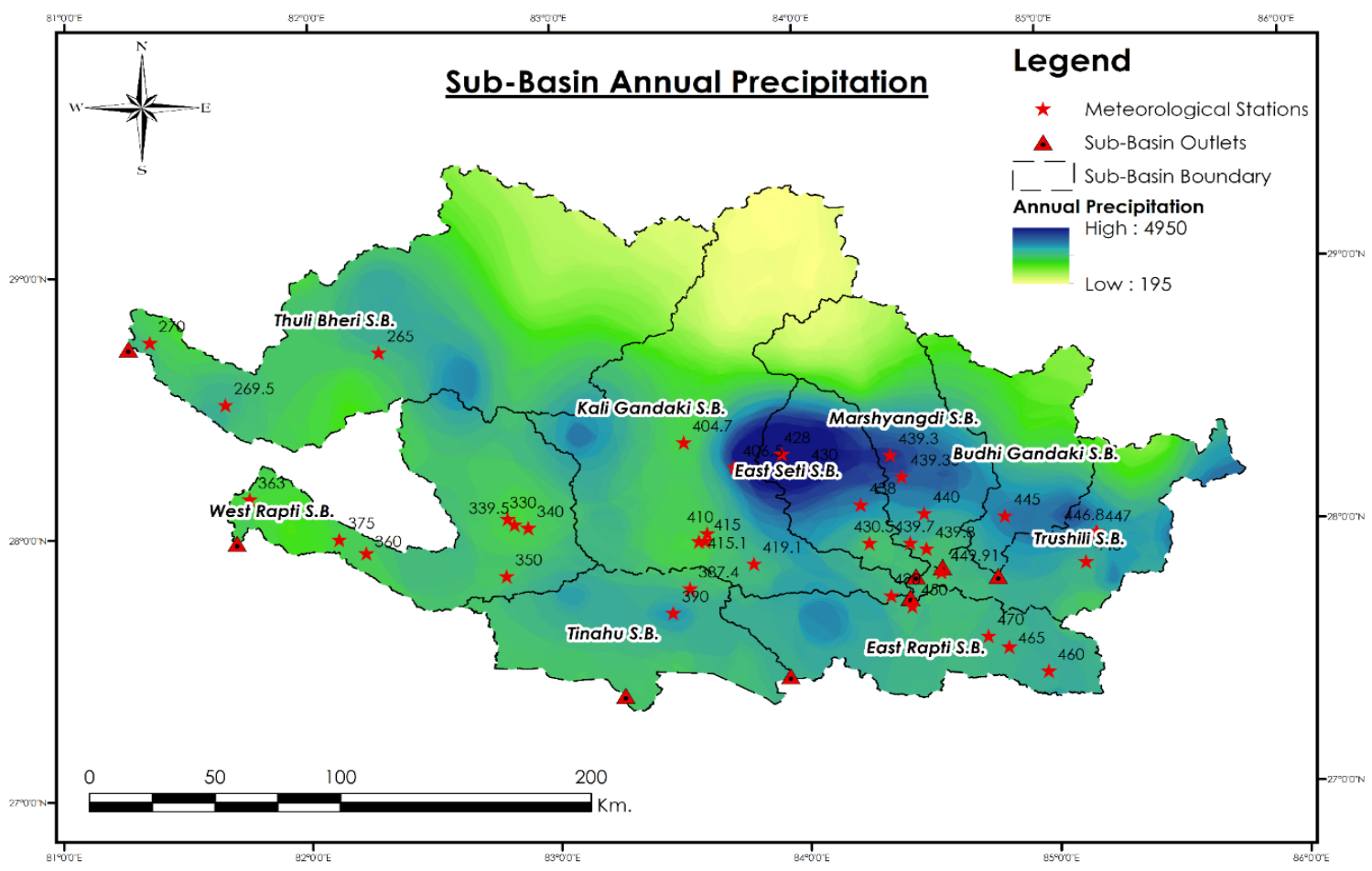

Figure 12: Annual Precipitation of sub-basins in Gandaki Province

\subsection{Watershed Analysis in Kaski District}

Kaski, a part of Gandaki Province is one of the seventy-seven districts of Nepal. Kaski district with Pokhara as its district headquarter, covers $2,017 \mathrm{~km}^{2}$ area. The altitude of Kaski district ranges from $450 \mathrm{~m}$ the lowest land to $8,091 \mathrm{~m}$ the highest point in the Himalaya range. Kaski district covers parts of the Annapurna mountain range. The district is full of rivers such as Seti Gandaki, Modi, and Madi along with other rivulets. The district headquarters Pokhara lies about $750 \mathrm{~m}$ above the sea level and is one of the best tourist destinations in the world. The district is famous for the Himalayan range with about eleven Himalayas with altitude greater than $7000 \mathrm{~m}$. The famous Peaks include Machhapuchhre (Virgin Peak - 6993 m). The
Annapurna Range in the northern side is always full of snow. The beautiful scenery of northern mountains, gorge of Seti River, Davis Falls, natural caves, Fewa Lake, and Begnas Lake are the main attractions. Major river networks in Kaski district are shown in Figure 13. Seti, Madi, Modi, and Mardi Khola are major rivers that flow from the upper Himalayas range and contribute most of water demand of people and infrastructure projects like hydropower and irrigation. A DEM of $12.5 \mathrm{~m}$ spatial resolution has been taken from Alaska Satellite Facility. The stream networks (rivers) were generated from flow accumulation raster, where threshold was taken as $25 \mathrm{~km}^{2}$. 


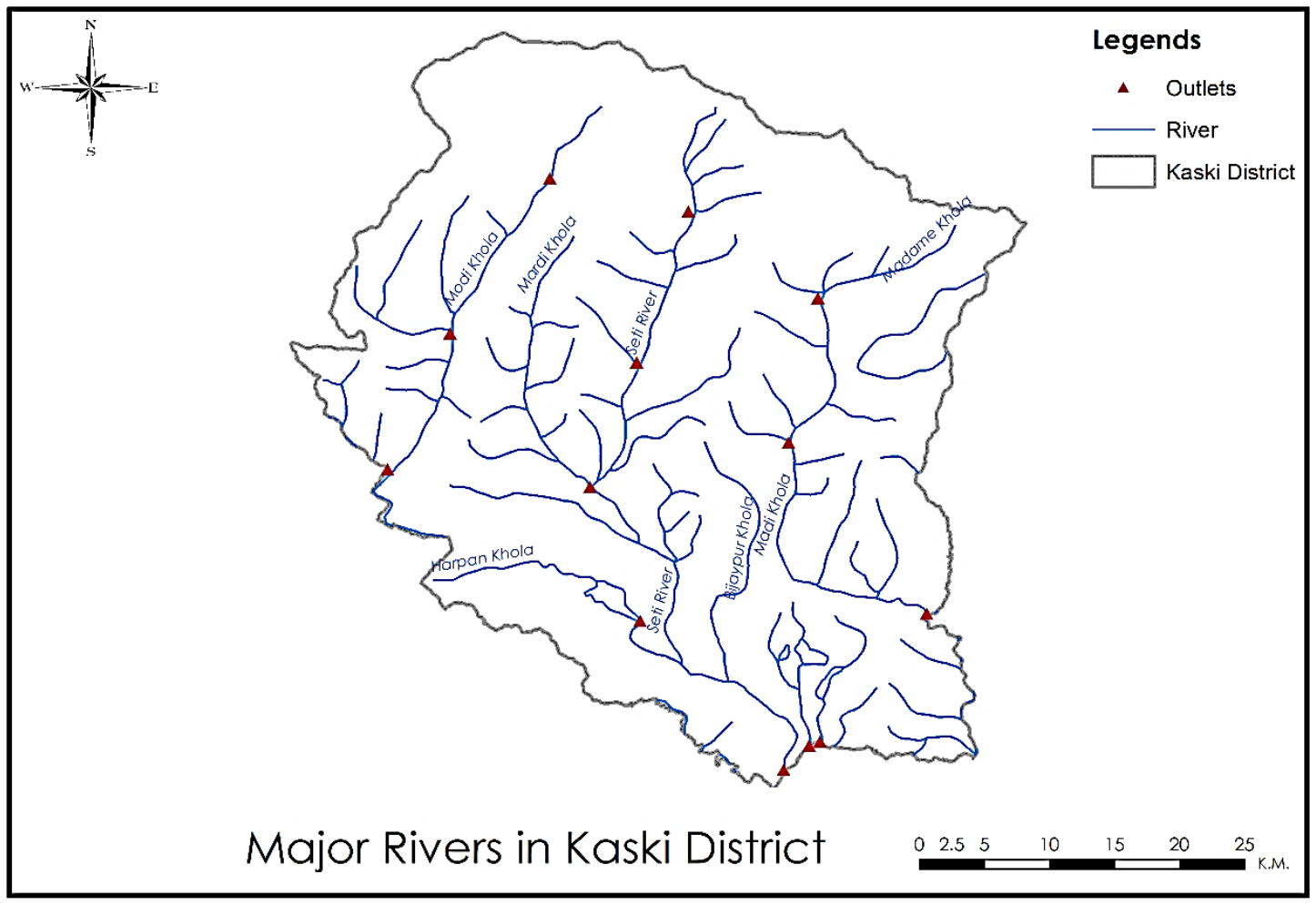

Figure 13: Major Rivers in Kaski District

Watersheds and stream network delineated within Kaski district can be visualized in Figure 14. This layer was derived from point-based watershed delineation method. The outlet points (point of interest) ware manually allocated to the stream location with higher accumulation and lowest elevation. Flow direction raster and snap pour point raster - which were derived from flow accumulation raster and point of interests - were used to delineate watersheds. Table 3 show name, area and major stream of the thirteen watersheds derived from the analysis. Study shows that the Seti-Bijaypur Watershed has higher drainage area of $267.378 \mathrm{~km}^{2}$ and Rupa Lake Watershed has lowest drainage area of $31.781 \mathrm{~km}^{2}$.
Table 3: Watersheds in Kaski District: Fact and Figures

\begin{tabular}{|c|c|c|c|c|}
\hline $\begin{array}{l}\text { S. } \\
\text { N. }\end{array}$ & Watersheds & $\begin{array}{l}\text { Area } \\
\left(\mathbf{K m}^{2}\right)\end{array}$ & $\%$ Area & Major Stream \\
\hline 1. & $\begin{array}{l}\text { South Annapurna } \\
\text { Glacier Watershed }\end{array}$ & 160.109 & $8.76 \%$ & Modi Khola \\
\hline 2. & $\begin{array}{l}\text { Machhapuchhre Glacier } \\
\text { Watershed }\end{array}$ & 117.439 & $6.43 \%$ & Seti River \\
\hline 3. & $\begin{array}{l}\text { Madme Khola } \\
\text { Watershed }\end{array}$ & 162.675 & $8.90 \%$ & $\begin{array}{l}\text { Madme Khola } \\
\text { Madi Khola }\end{array}$ \\
\hline 4. & $\begin{array}{l}\text { Upper Modi Khola } \\
\text { Watershed }\end{array}$ & 173.339 & $9.48 \%$ & Modi Khola \\
\hline 5. & $\begin{array}{l}\text { Upper Seti River } \\
\text { Watershed }\end{array}$ & 135.883 & $7.43 \%$ & Seti River \\
\hline 6. & $\begin{array}{l}\text { Upper Madi Khola } \\
\text { Watershed }\end{array}$ & 188.503 & $10.31 \%$ & Madi Khola \\
\hline 7. & $\begin{array}{l}\text { Lower Modi Khola } \\
\text { Watershed }\end{array}$ & 66.109 & $3.62 \%$ & Modi Khola \\
\hline 8. & Mardi Khola Watershed & 233.693 & $12.79 \%$ & $\begin{array}{l}\text { Mardi Khola } \\
\text { Seti River }\end{array}$ \\
\hline 9. & $\begin{array}{l}\text { Lower Madi Khola } \\
\text { Watershed }\end{array}$ & 130.051 & $7.12 \%$ & Madi Khola \\
\hline 10. & Phewa Lake Watershed & 121.610 & $6.65 \%$ & Harpan Khola \\
\hline 11. & Rupa Lake Watershed & 31.781 & $1.74 \%$ & $\begin{array}{l}\text { Dovan Khola } \\
\text { Tabesi Khola }\end{array}$ \\
\hline 12. & Begnas Lake Watershed & 39.239 & $2.15 \%$ & Khudi Khola \\
\hline 13. & Seti-Bijaypur Watershed & 267.378 & $14.63 \%$ & $\begin{array}{l}\text { Seti River } \\
\text { Bijaypur Khola }\end{array}$ \\
\hline
\end{tabular}




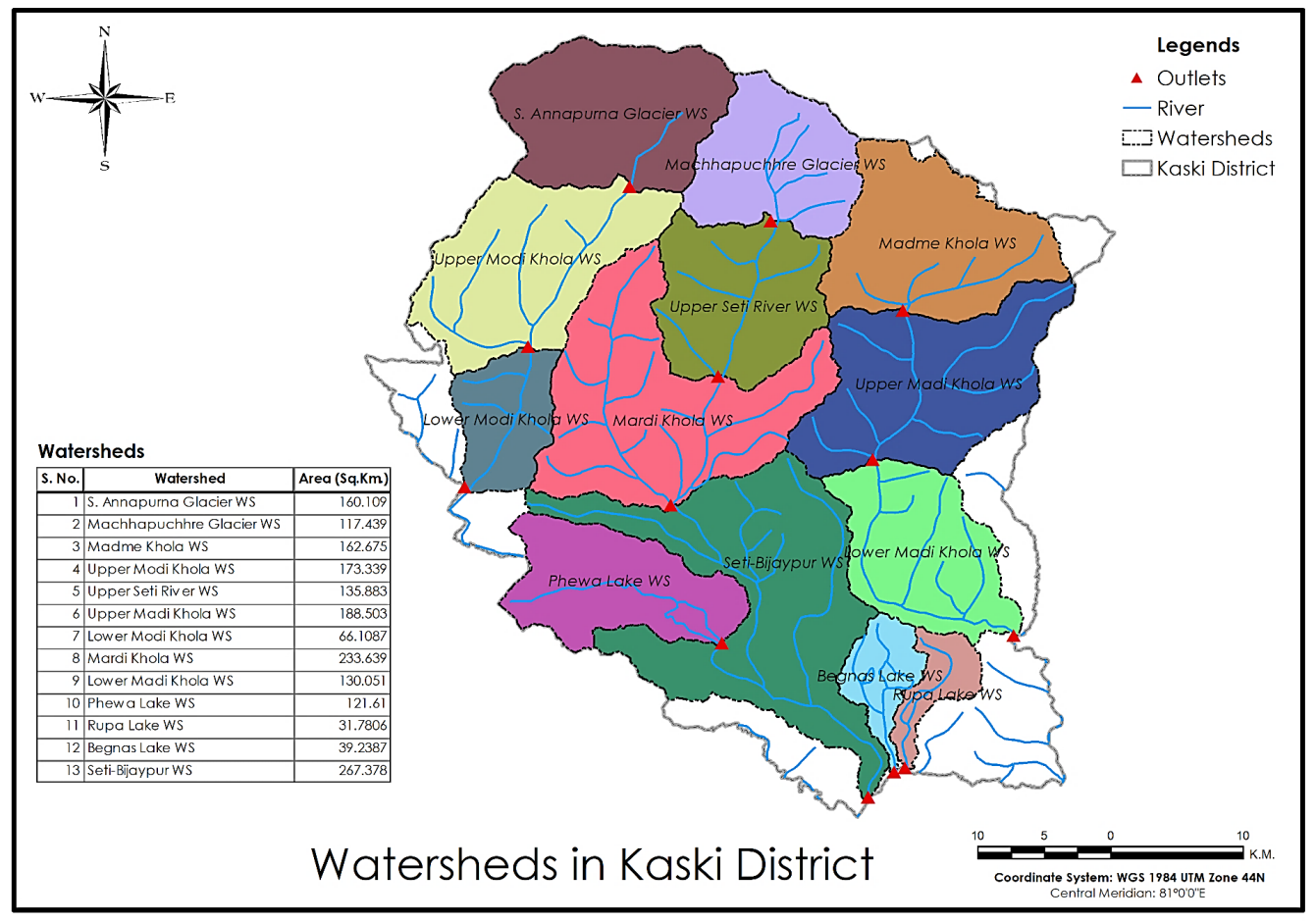

Figure 14: Watersheds and stream network delineation of Kaski District

\section{Conclusion}

The analysis of Phewa watershed conducted in details. The drainage area obtained is $121.61 \mathrm{~km}^{2}$ and it was observed that the area is similar to the previous studies. The morphometric analysis of watershed in Gandaki Province was conducted in Sub-Basin level and it was found that there are nine numbers of sub-basins in Gandaki Province. It was observed that only two subbasins: East-Seti Sub-Basin with total drainage area of $2959.02 \mathrm{~km}^{2}$ and Marshyangdi SubBasin with total drainage area of $4798.66 \mathrm{~km}^{2}$ are completely within the province boundary. Most of the area of Gandaki Province has been occupied by Kali Gandaki Sub-Basin with total drainage area of $11839.8 \mathrm{Km}^{2}$ where maximum average annual rainfall of $4990 \mathrm{~mm}$ observed. Least drainage area of $2959.02 \mathrm{~km}^{2}$ is occupied by East Seti Sub-Basin with maximum annual precipitation of $4950 \mathrm{~mm}$. The West Rapti Sub-
Basin has minimum average annual precipitation of $2700 \mathrm{~mm}$ as compared to other sub-basins. None of the Sub-Bains has been observed with regular/circular shape, all are elongated shaped. Since the sub-basins are elongated shaped, smaller peak flooding is possible. The East Seti Sub-Basin has steeper slope of 0.0307, while Tinahu Sub-Basin has minor slope of 0.0076 . The Watersheds analysis for Kaski District has been performed and it was found that there are thirteen numbers of watersheds, where SetiBijaypur watershed has larger drainage area of $267.378 \mathrm{~km}^{2}$.

The results observed in the present work can be used as a reference for site suitability analysis of infrastructures in those watersheds. These parameters can be integrated with other hydrological information viz, land use/ land cover, geology, water level and soils in 
GIS domain for decision making regarding soil and water conservation structures (check dam, nala bund, etc.) in those area for ground water development and management by local government authorities related to Energy, Water Resources, Irrigation, and Infrastructures. The study recommended that the watersheds need hydrogeological and geophysical investigation in future for proper water management and development of infrastructure within the study area. However, the present work can be a reference for academic researchers and young scientists, who are working on water management projects.

\section{References}

Aryal, V. (2007). Phewa Lake Watershed Area: A Study on the Challenges to Human Encroachment. In M. Sen Gupta, \& R. Dalwani (Ed.), Proceedings of Taal 2007: The 12th World Lake Coference. Jaipur, India: International Lake Environment Committee: 2292-2299.

Basnet, K., Baniya, U., \& Karki, S. (2018). "Comparative Study of Design Discharge Calculation Approaches: A Case Study on Padhu Khola, Kaski, Nepal." Oodbodhan: A Journal of TUTA, Pashchimanchal Campus, 5 (5).

Basnet, K., \& Neupane M. (2018). "Storm Water Drainage Design Based on HydrologicAnalysis: A Case Study on Lamachaur Catchment Area, Pokhara, Nepal." Oodbodhan: A Journal of TUTA, Pashchimanchal Campus, 5 (5).

How Watershed works. (n.d.). Retrieved July 2018, from ArcGIS Desktop: http://pro.arcgis. com/en/pro-app/tool-reference/spatial-analyst/ how-watershed-works.htm.

Hydrological Analysis. (n.d.). Retrieved July 2018, from Documentation QGIS 2.8: https:// docs.qgis.org/2.8/en/docs/training_manual/ processing/hydro.html.
Ma, Y. (2004). GIS Application In Watershed Management. Nature and Science.

Mason, D., \& Maidment, D. R. (2000). An Analysis of a Methodology for Generating Watershed Parameters using GIS. J.J. Pickle Research Campus, Bureau of Engineering Research, The University of Texas at Austin, Center For Research In Water Resources, Austin. Retrieved May 2018, from http://www.crwr. utexas.edu/online.html.

Province Profile, Province No. 4. (n.d.). Retrieved July 2018, from Provincial Government, Gandaki Province Website: http://www.p4ocmcm.gov.np/upload/ news/1520422912_Province_Profile.pdf.

Rivas, B. L., \& Koleva-Lizama, I. (2017, January 23). GIS Technology in Watershed Analysis. Retrieved from https://www.researchgate.net/ publication/254908137

Sahayogee, J. (n.d.). Proposed States or Province in Nepal. Retrieved May 2018, from http:// www.imnepal.com/states-nepal.

Sreedevi, P., Sreekanth, P., Khan, H., \& Ahmed, S. (2013). Drainage Morphometry and Its Influence on Hydrology in an Semiarid Region: Using SRTM Data and GIS. Environ. Earth Sci, 70 (2), 839-848.

Subedi, D. S. (2013). Application of Geoinformatics on Land Use Dynamic of Phewa Lake Watershed, Pokhara, Nepal. (B. P. Adhikari, Ed.) The Himalayan Geographers.

Watershed Analysis: What, How, Influencing Factors \& Applications. (2015, July 12). Retrieved from GIS Resources: A Knowledge Archive: http://www.gisresources.com/ giswatershedwatershed-analysis.

Watershed Plans: Protecting and Restoring Water Quality. (n.d.). New York State Department of State, Office of Coastal, Local Government and Community Sustainability. 